\title{
Impacts on the Output Power of Photovoltaics on Top of Electric and Hybrid Electric Vehicles
}

\author{
Christian Schuss, Member, IEEE, Tapio Fabritius, Bernd Eichberger, and Timo Rahkonen, Member, IEEE
}

\begin{abstract}
This paper investigates the potential output power of a photovoltaic (PV) installation on top of battery-powered electric vehicles (BEVs) and hybrid electric vehicles (HEVs). Firstly, we discuss the available area on the roof of BEVs and HEVs for deploying PV cells. Secondly, we verify the impact of the vehicles curved roof surface on the available output power of photovoltaics. More precisely, we present a method of calculating the effective area of PV cells, useful for PV simulation models and calculating the available output power of PV cells with different longitudinal angles. We verify our method within experiments and present the results of them, showing that the model predicts the output power of PV cells with an accuracy better than $2.5 \%$. Furthermore, we discuss the impact of the curved surface and ambient conditions on possible interconnections of PV cells. Here, we present considerations for both, stationary and moving conditions, to highlight the difficulties for interconnecting PV cells to form PV panels. From our experimental results, for frequent changes in the available solar radiation level, we can see a difference in terms of output power larger than $75 \%$ between series and parallel interconnections of PV cells.
\end{abstract}

Index Terms-battery-powered electric vehicle, data acquisition, environmental data, hybrid electric vehicle, measurement, photovoltaic energy, simulation, solar energy.

\section{INTRODUCTION}

A $\mathrm{T}$ present, solar energy is the most promising energy source [1], in particular to substitute energy gained from fossil fuels such as oil, coal and gas [2]. In future, the opportunity is given to integrate photovoltaic (PV) cells into the roof of battery-powered vehicles (BEVs) and hybrid electric vehicles (HEVs). As a result, the electrical driving range of these types of vehicles can be extended remarkably [3][6]. Similarly, photovoltaics can be used to power a charging station for BEVs and HEVs, for example [7].

Due to the technical development of automobiles, their electricity consumption has grown significantly over the past years and electronic control units (ECUs) have become the key components in automotives $[8]$. Their objectives include the control of the power train, as well as safety and comfort requirements. In the case of HEVs, an additional demand of 100 Watts electrical power increases the fuel consumption by 0.1 to 0.2 litres per 100 kilometres [8], [9]. Similarly, in the

This work was financially supported by Infotech Oulu. Dr. Christian Schuss and Prof. Tapio Fabritius are partially funded by the Academy of Finland 6Genesis (6G) Project (grant no. 318927). Prof. Tapio Fabritius was also supported by the Academy of Finland's FIRI funding (grant no. 320017).

C. Schuss, and T. Rahkonen are with the Circuits and Systems (CAS) Research Unit, University of Oulu, 90014 Oulu, Finland (e-mail: christian.schuss@oulu.fi).

B. Eichberger is with the Institute of Electronic Sensor Systems, Graz University of Technology, 8010 Graz, Austria.

Final Version December 18, 2019 case of BEVs, the electrical driving distance is reduced by electronics. In order to maximize the operational range of HEVs and BEVs, alternative energy harvesting methods such as photovoltaics are considered.

It is clear that the available output power obtainable from photovoltaics is too low to provide enough energy for the propulsion of BEVs and HEVs directly [10]. Hence, we propose to use PV energy as an energy range extender (ERE) and, thereby, reduce the amount of electricity which has to be provided by the alternator or energy demanded from the power grid for charging the high-voltage battery [11]. PV energy can be supplied to non-critical systems within the on-board power grid when driving. Likewise, the high-voltage battery can be charged by the PV installation when the vehicle is parked. The available area on top of BEVs and HEVs is limited and the curved shape of the roof has an impact on the available output power of the PV installation on top of BEVs and HEVs [3][6]. To optimize the ERE performance in these circumstances, more sophisticated methods and models are needed in order to estimate the power generation of photovoltaics.

Araki et al. [4] summarise the required research and development $(R \& D)$ tasks to enable PV installations on top of majority of BEVs and HEVs. In their work, the need for PV simulation models is emphasised, for example to provide energy predictions and forecasts on the available energy from the vehicle's PV installation. Ota et al. [12] present a multi pyranometer array to obtain the available solar radiation level. The focus of their work lies in measuring the direct and diffuse components of sunlight on top of a stationary vehicle. Yamaguchi et al. [13] investigate the potential efficiency of nextgeneration PV cells. In particular, the pathway toward higher efficiency for PV cells is discussed. These research efforts contribute to the maximisation of the degree of efficiency of PV installations on top of BEVs and HEVs.

In this paper, we extend our analyses presented in [14] related to possible impacts on the available output power of PV cells on top of BEVs and HEVs. More precisely, we focus on possible interconnections of PV cells to form PV panels. Firstly, we concentrate on stationary conditions, in other words when vehicles with PV installations are parked within urban areas. In our analyses, we concentrate on the impact of the weakest PV cell (i.e. the PV cell exposed to the lowest solar radiation level) on the output power of the interconnection of PV cells. We show the difference between series and parallel connections of PV cells. Based on our experimental results, due to the curved surface of the vehicle's roof, about $25 \%$ less power can be obtained from a series connection compared to a parallel connection of PV cells. 
Secondly, we investigate moving conditions, in other words when vehicles with PV installations are driving within urban areas. In this case scenario, our experimental data shows frequent changes in the available solar radiation level, in particular, when the vehicle passes for example through tree avenues. Furthermore, the experimental data reveals an uneven distribution of the shading on top of vehicles. Even though the size of the vehicle's roof is only about $1.5 \mathrm{~m}^{2}$, about $30 \%$ less irradiation is available from one side to the other side of the vehicle. These circumstances have a significant impact on finding the optimal desgin and type of interconnections for PV cells. Our data shows that especially during frequent changes in the available solar radiation level, a series connection of PV cells provides about $75 \%$ less power in comparison to a parallel connection of PV cells.

The structure of this paper is as follows: Section II discusses the available output power of photovoltaics. In Section III, we present the concept of the effective area of PV cells, useful to consider different longitudinal angles of PV cells towards the sun. Such different longitudinal angles occur when installing PV cells on top of curved surfaces such as the roof of vehicles. In Section IV, we present experimental results and analyse the influence of stationary and moving conditions on possible interconnections of PV cells. In particular, we illustrate the disadvantages and losses of series connections compared to parallel connections of PV cells. We present discussions and conclusions in Section V and VI.

\section{BACKGROUND OF THE RESEARCH}

\section{A. Output Behaviour of Photovoltaics}

Fig. 1 illustrates the characteristic non-linear output behaviour of a PV cell from the manufacturer Blue Chip Energy $\mathrm{GmbH}$ in the form of the $I-V$ (Current-Voltage) curve and $P-V$ (Power-Voltage) curve. The point on the $I-V$ curve, in which the product of voltage and current, the power, becomes a maximum is referred to as the maximum power point (MPP). The available power in the MPP $\left(P_{m p p}\right)$ varies with changing ambient conditions such as the solar radiation level $(\lambda)$ and the PV cell temperature $\left(T_{c}\right)$ [15].

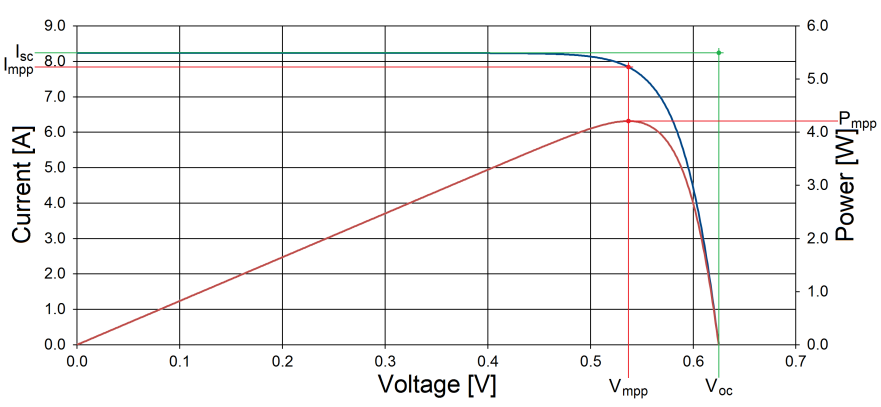

Fig. 1. $I-V$ curve and $P-V$ curve of a PV cell with parameters

\section{B. PV Simulation Model}

Simulations are helpful for determining the potential output power of photovoltaics under different solar radiation levels. Commonly, the single diode model is used as an equivalent

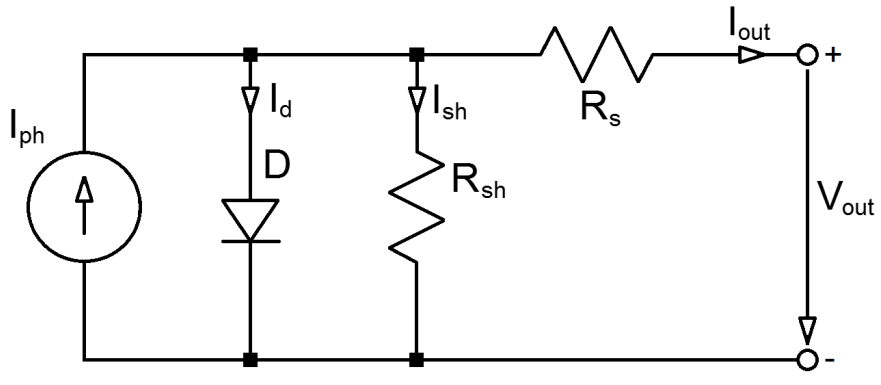

Fig. 2. Equivalent circuit of a PV cell

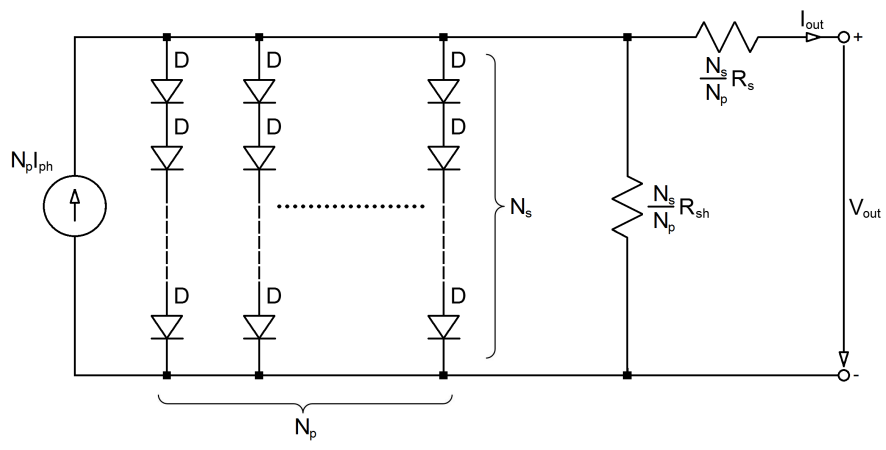

Fig. 3. Equivalent circuit of a PV panel

electric circuit for the simulation of one PV cell [16]-[20]. The short circuit-current of the PV cell $\left(I_{s c}\right)$ is directly proportional to the solar radiation level $(\lambda)$. In the case of the single-diode model, the output current $\left(I_{\text {out }}\right)$ can be obtained as follows

$$
\begin{array}{r}
I_{\text {out }}=N_{p} I_{\text {ph }}-N_{p} I_{s}\left(e^{\frac{q\left(N_{p} V_{\text {out }}+N_{s} I_{\text {out }} R_{s}\right)}{N_{p} N_{s} A k T_{c}}}-1\right) \\
-\frac{\frac{N_{p}}{N_{s}} V_{\text {out }}+I_{\text {out }} R_{s}}{R_{\text {sh }}}
\end{array}
$$

where $N_{p}$ is the number of PV cells connected in parallel with one other; $I_{p h}$ is the photo current; $I_{s}$ is the saturation current; $q$ is the charge of an electron; $V_{\text {out }}$ is the output voltage of the PV cell; $N_{s}$ is the number of PV cells connected in series with one other; $R_{S}$ is the series resistance; $A$ is the ideality factor of the p-n junction, $k$ is Bolzmann's constant; and $R_{s h}$ is the shunt resistance. It is worth noting that there are several more equations required to fully describe and calculate the equivalent circuit of a PV cell [19]. The equivalent circuit of a PV cell is shown in 2, while the equivalent circuit of a PV panel is shown in Fig. 3 .

\section{Establishing Interconnections of PV Cells}

As mentioned above, in PV simulation models, by the use of the parameters $N_{s}$ and $N_{p}$, each PV cell in a panel is considered to be equal to the others. In this way, also the solar radiation level $(\lambda)$ and PV cell temperature $\left(T_{c}\right)$ is assumed to be equal for every PV cell. Commonly, PV panels are made out of a large series connection of PV cells. However, if one of the PV cells in the panel receives less sunlight than the other ones, which is the case for PV installations on top of curved 
surfaces such as the roof of BEVs and HEVs, the PV panel performance is significantly decreased.

In a series connection of PV cells, the short-circuit current $\left(I_{s c}\right)$ depends on the short-circuit current of the weakest PV cell of the interconnection $\left(I_{s c, \min }\right)[21]-[23]$, as obtained as follows:

$$
P_{\text {ideal }}=V_{o c} \times I_{s c, \text { min }} \quad \text { whereas } \quad I_{s c, \text { min }}<I_{s c}
$$

where $P_{\text {ideal }}$ is the ideal power of the PV panel and $V_{o c}$ is the open-circuit voltage of the PV panel.

\section{EXPerimental Setup ANd Procedure}

\section{A. Photovoltaics within Experiments}

Since the available space on top of BEVs and HEVs is limited we suggest using superior PV cells with high efficiencies and high output currents. As a result, a significant amount of PV energy can be produced and provided to the on-board power supply of vehicles. Thus, a monocrystalline silicon (mono-Si) PV cell was used in experiments and simulations. The dimension of one PV cell is $156 \times 156$ millimetres. Table [1] summarises the most important output parameters obtained from the datasheet of the manufacturer Blue Chip Energy $\mathrm{GmbH}$.

TABLE I

Data of The BLue Chip PV CELL

\begin{tabular}{|c|c|}
\hline Parameter & Value \\
\hline$P_{m p p}$ & $4.140 \mathrm{~W}$ \\
\hline$V_{m p p}$ & $0.515 \mathrm{~V}$ \\
\hline$I_{m p p}$ & $8.039 \mathrm{~A}$ \\
\hline$V_{o c}$ & $0.613 \mathrm{~V}$ \\
\hline$I_{s c}$ & $8.602 \mathrm{~A}$ \\
\hline
\end{tabular}

AM1.5; $\lambda=1,000 \mathrm{~W} / \mathrm{m}^{2} ; T_{c}=25{ }^{\circ} \mathrm{C} ;$ standard test conditions (STC)

\section{B. Possible Number of PV Cells}

Fig. 4 shows the experimental vehicle, a Toyota Prius, which was used for measurements and analysing the impact of different alignments and orientations of PV cells towards the sun. In addition, the experimental vehicle was used to study the impact of ambient conditions on the output performance of PV cells. Fig. 5 illustrates the available area for PV cells on the roof of the Toyota Prius.

Due to the curved shape of the roof of the Toyota Prius, it is not possible to utilise $100 \%$ of the roof's area for the installation of PV cells [4]. On average, the available area on the roof of BEVs and HEVs varies between 1.5 and $2 \mathrm{~m}^{2}$. The roof of the Toyota Prius is wider at the front than at the back, while it is even smaller in the middle. Hence, we have chosen a number of $45 \mathrm{PV}$ cells $\left(n_{\text {cells,row }}=9, n_{\text {cells,line }}=5\right)$, as illustrated in Fig. 5. PV cells are connected in series or parallel in order to increase the output power. When connecting PV cells in series, the open-circuit voltage $\left(V_{o c}\right)$ increases, while in parallel structures, the short-circuit current $\left(I_{s c}\right)$ increases.

It is worth noting that there are also currently a few commercial solutions available for PV installations for HEVs. For the

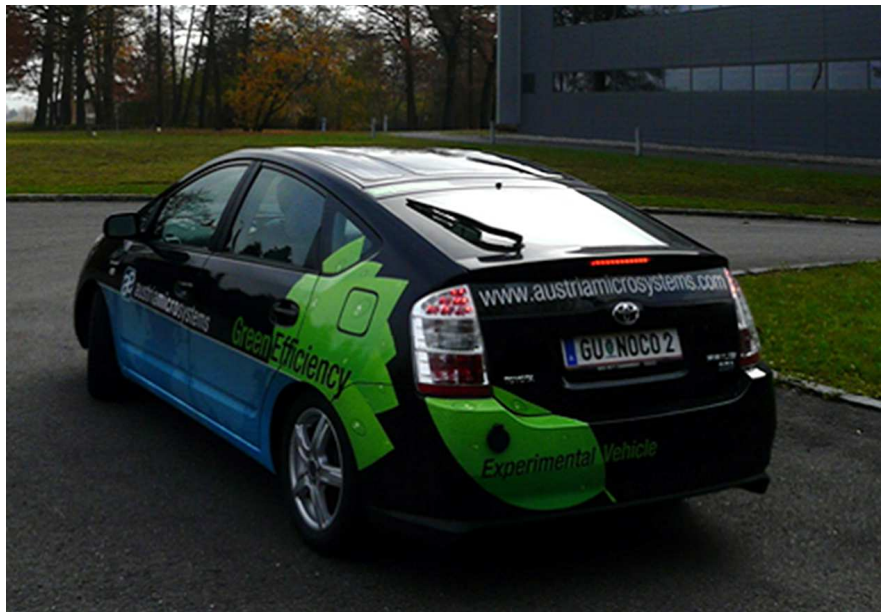

Fig. 4. Experimental vehicle with integrated PV cells

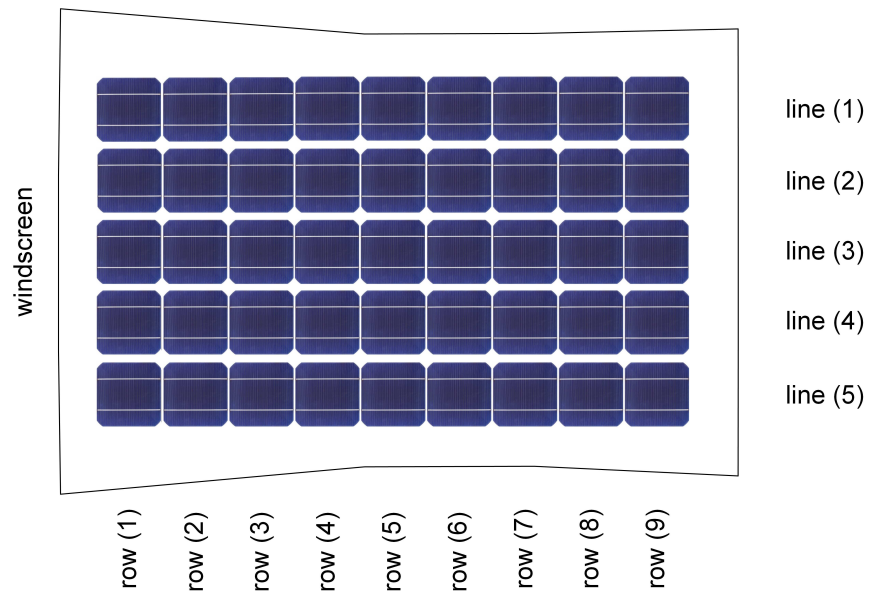

Fig. 5. PV installation on top of the experimental vehicle

experimental vehicle, the Toyota Prius, an optional PV panel can be purchased which is located at the rear end of the roof. The PV panel is used for powering the air conditioning system, while the vehicle is parked. If the vehicle is parked in the sun, the obtained energy from the integrated PV panel can be used to cool the interior of the vehicle. In contrast to commercial available solutions, in which commonly PV cells are connected in series, the PV installation on top of the experimental vehicle allows to access each PV cell individually.

\section{Calculation of the Effective Area}

For the PV installation on top of the Toyota Prius, PV cells can be connected in series and/or parallel with each other to form a PV panel [4], as illustrated in Fig. 3. For a single PV cell, $N_{s}$ and $N_{p}$ are equal to 1 . In PV simulations, one coefficient for the solar radiation level $(\lambda)$ and one for the cell temperature $\left(T_{c}\right)$ are applied. In other words, the assumption is made that each cell of the PV panel is exposed to an equal amount of sunlight and operates at the same temperature level. This assumption can be made in the case of conventional PV panels which are mounted onto flat surfaces, for example on the roof of a house. 
TABLE II

LONGITUDINAL ANGLES OF PV CELLS $(\beta)$ ON THE ROOF OF THE EXPERIMENTAL VEHICLE

\begin{tabular}{|c|c|c|c|c|c|c|c|c|}
\hline row (1) & row (2) & row (3) & row (4) & row (5) & row (6) & row (7) & row (8) & row (9) \\
\hline $15^{\circ}$ & $12^{\circ}$ & $9^{\circ}$ & $3^{\circ}$ & $2^{\circ}$ & $0^{\circ}$ & $-3^{\circ}$ & $-7^{\circ}$ & $-9^{\circ}$ \\
\hline
\end{tabular}

However, if photovoltaics are mounted onto curved surfaces such as the top of a vehicle, each cell of the PV panel will obtain a different amount of sunlight and operate at a different temperature. The variation in output power depends on the solar altitude and alignment of individual PV cells of the panel towards the sun. This situation is comparable to partial shading of PV panels, which can occur temporarily during cloudy days or in the proximity of shading objects like trees [16]. In this paper, we focus on the effective area $\left(A_{\text {eff }}\right)$ to consider different longitudinal angles of PV cells towards the sun in PV simulation models.

As a result of the curved shape of the roof of the experimental vehicle, the five PV cells in each row have a different orientation towards the sun. Table $\Pi$ summarises the longitudinal angles $(\beta)$ of the PV cells from row number (1) to (9). The street represents the horizontal plane. Based on these longitudinal angles, there is a difference in the orientation of $24^{\circ}$ between the PV cells in row number (1) and row number (9). Beside a different orientation of PV cells in each row, the curved shape of the vehicle's roof can also cause a different orientation of PV cells in each line. Often, the shape of the vehicle's roof can be curved in various ways.

Fig. 6 shows the actual roof of the experimental vehicle. As seen in Fig. 6 on the uneven reflections of the building in the background, the roof is curved three times. We used a carbon-based, flexible and light-weight structure to smoothen the uneven original roof of the experimental vehicle for the PV installation. As a result, PV cells in each line among one row have the same longitudinal angle, which is summarised in Table III. However, without smoothing the uneven shape of the vehicle's roof, each line within one row would have different longitudinal angles.

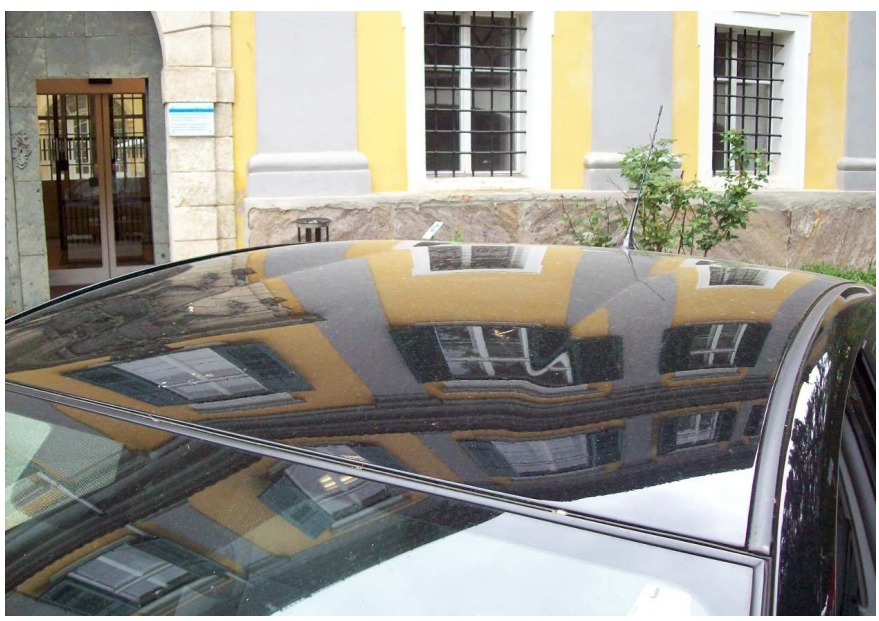

Fig. 6. Actual roof of the experimental vehicle

Fig. 7 shows the effective PV cell area $\left(A_{\text {eff }}[\%]\right)$ based on the different orientation of PV cells at different solar altitude angles $(\alpha)$. $A_{\text {eff }}$ was calculated in MATLAB ${ }^{\circledR}$ by using the perpendicular area without taking diffuse irradiation and possible total reflections into account, as follows

$$
A_{\text {eff }}=\cos \left(\alpha+\beta-90^{\circ}\right) \times 100
$$

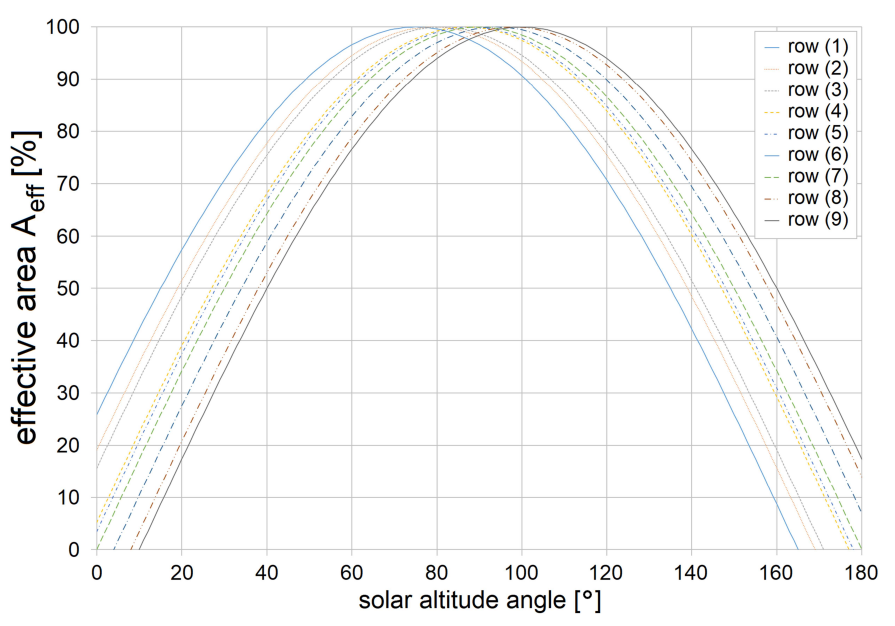

Fig. 7. Effective PV cell areas at different solar altitude angles

Table III presents the effective area $\left(A_{\text {eff }}\right)$ calculated at different solar altitude angles. As seen in Table IIII there is a significant difference in $A_{\text {eff }}$ between row (1) and row (9). For a better comparison, the calculated values for the effective area are normalised. The highest value in each row at a given solar altitude is considered to be $100 \%\left(A_{\text {eff, } \text { max }}\right)$, as obtained by Equation (3). In other rows, lower values are obtained due to the different orientation of the other PV cells towards the sun.

$$
\hat{A}_{e f f}=\frac{A_{e f f, i}}{A_{\text {eff,max }}} \quad \text { whereas } \quad i=1,2, \ldots, 8,9
$$

Table IV presents the normalised effective area $\left(\hat{A}_{e f f}\right)$. The difference in $\hat{A}_{\text {eff }}$ depends greatly on the solar altitude angle $(\alpha)$. At $\alpha=90^{\circ}$, the difference in $\hat{A}_{\text {eff }}$ between row (1) and (9) is less than $5 \%$, while at $\alpha=20^{\circ}$ and $\alpha=160^{\circ}$ the difference in $\left(\hat{A}_{\text {eff }}\right)$ is about 70 to $80 \%$. These differences are important and need to be taken into account when planning interconnections of PV cells. Tables $\mathrm{V}$ and $\mathrm{VI}$ show the effective area $\left(A_{\text {eff }}\right)$ and normalised effective area $\left(\hat{A}_{\text {eff }}\right)$ for typical solar radiation altitudes $\left(\alpha=38^{\circ}\right.$ to $\left.44^{\circ}\right)$ in the City of Oulu, Finland, during June.

\section{EXPERIMENTAL RESULTS}

\section{A. Experimental Verification of the Effective Area}

We conducted experiments to verify the accuracy of the calculated results shown in Tables $\mathrm{V}$ and $\mathrm{VI}$. In the exper- 
TABLE III

Calculated efFective AREa of PV Cells $\left(A_{e f f}\right)$ AT DifFerent Solar Altitude ANGLes $(\alpha), \alpha=20^{\circ}$ To $160^{\circ}$

\begin{tabular}{|c|c|c|c|c|c|c|c|c|c|}
\cline { 2 - 10 } \multicolumn{1}{c|}{} & $\alpha=20^{\circ}$ & $\alpha=40^{\circ}$ & $\alpha=60^{\circ}$ & $\alpha=75^{\circ}$ & $\alpha=90^{\circ}$ & $\alpha=1055^{\circ}$ & $\alpha=120^{\circ}$ & $\alpha=140^{\circ}$ & $\alpha=160^{\circ}$ \\
\hline row (1) & $57.36 \%$ & $81.92 \%$ & $96.59 \%$ & $100.00 \%$ & $96.59 \%$ & $86.60 \%$ & $70.71 \%$ & $42.26 \%$ & $8.72 \%$ \\
\hline row (2) & $51.50 \%$ & $77.71 \%$ & $94.55 \%$ & $99.76 \%$ & $98.16 \%$ & $89.88 \%$ & $75.47 \%$ & $48.48 \%$ & $15.64 \%$ \\
\hline row (3) & $48.48 \%$ & $75.47 \%$ & $93.36 \%$ & $99.45 \%$ & $98.77 \%$ & $91.35 \%$ & $77.71 \%$ & $51.50 \%$ & $19.08 \%$ \\
\hline row (4) & $39.07 \%$ & $68.20 \%$ & $89.10 \%$ & $97.81 \%$ & $99.86 \%$ & $95.11 \%$ & $83.87 \%$ & $60.18 \%$ & $29.24 \%$ \\
\hline row (5) & $37.46 \%$ & $66.91 \%$ & $88.29 \%$ & $97.44 \%$ & $99.94 \%$ & $95.63 \%$ & $84.80 \%$ & $61.57 \%$ & $30.90 \%$ \\
\hline row (6) & $34.20 \%$ & $64.28 \%$ & $86.20 \%$ & $96.59 \%$ & $100.00 \%$ & $96.59 \%$ & $86.60 \%$ & $64.28 \%$ & $34.20 \%$ \\
\hline row (7) & $27.56 \%$ & $58.78 \%$ & $82.90 \%$ & $94.55 \%$ & $99.76 \%$ & $98.16 \%$ & $89.88 \%$ & $69.47 \%$ & $40.67 \%$ \\
\hline row (8) & $20.79 \%$ & $52.99 \%$ & $78.80 \%$ & $92.05 \%$ & $99.03 \%$ & $99.25 \%$ & $92.72 \%$ & $74.31 \%$ & $46.95 \%$ \\
\hline row (9) & $17.36 \%$ & $50.00 \%$ & $76.60 \%$ & $90.63 \%$ & $98.48 \%$ & $99.62 \%$ & $93.97 \%$ & $76.60 \%$ & $50.00 \%$ \\
\hline
\end{tabular}

TABLE IV

Normalised EFFective AREA OF PV CELls $\left(\hat{A}_{e f f}\right)$ AT DIFFERENT SOLAR ALtitUde ANGLEs $(\alpha), \alpha=20^{\circ}$ TO $160^{\circ}$

\begin{tabular}{|c|c|c|c|c|c|c|c|c|c|}
\cline { 2 - 9 } \multicolumn{1}{c|}{} & $\alpha=20^{\circ}$ & $\alpha=40^{\circ}$ & $\alpha=60^{\circ}$ & $\alpha=75^{\circ}$ & $\alpha=900^{\circ}$ & $\alpha=105{ }^{\circ}$ & $\alpha=120^{\circ}$ & $\alpha=140^{\circ}$ & $\alpha=160{ }^{\circ}$ \\
\hline row (1) & $100.00 \%$ & $100.00 \%$ & $100.00 \%$ & $100.00 \%$ & $96.59 \%$ & $86.93 \%$ & $75.25 \%$ & $55.17 \%$ & $17.44 \%$ \\
\hline row (2) & $89.78 \%$ & $94.86 \%$ & $97.89 \%$ & $99.76 \%$ & $98.16 \%$ & $90.22 \%$ & $80.31 \%$ & $63.29 \%$ & $31.28 \%$ \\
\hline row (3) & $84.52 \%$ & $92.13 \%$ & $96.66 \%$ & $99.45 \%$ & $98.77 \%$ & $91.70 \%$ & $82.70 \%$ & $67.23 \%$ & $38.16 \%$ \\
\hline row (4) & $68.11 \%$ & $83.25 \%$ & $92.25 \%$ & $97.81 \%$ & $99.86 \%$ & $95.47 \%$ & $89.25 \%$ & $78.56 \%$ & $58.48 \%$ \\
\hline row (5) & $65.31 \%$ & $81.68 \%$ & $91.41 \%$ & $97.44 \%$ & $99.94 \%$ & $95.99 \%$ & $90.24 \%$ & $80.38 \%$ & $61.80 \%$ \\
\hline row (6) & $59.62 \%$ & $78.47 \%$ & $89.24 \%$ & $96.59 \%$ & $100.00 \%$ & $96.96 \%$ & $92.16 \%$ & $83.92 \%$ & $68.40 \%$ \\
\hline row (7) & $48.05 \%$ & $71.75 \%$ & $85.83 \%$ & $94.55 \%$ & $99.76 \%$ & $98.53 \%$ & $95.65 \%$ & $90.69 \%$ & $81.34 \%$ \\
\hline row (8) & $36.24 \%$ & $64.69 \%$ & $81.58 \%$ & $92.05 \%$ & $99.03 \%$ & $99.63 \%$ & $98.67 \%$ & $97.01 \%$ & $93.90 \%$ \\
\hline row (9) & $30.26 \%$ & $61.04 \%$ & $79.30 \%$ & $90.63 \%$ & $98.48 \%$ & $100.00 \%$ & $100.00 \%$ & $100.00 \%$ & $100.00 \%$ \\
\hline
\end{tabular}

iments, the front of the vehicle was orientated towards the sun. We collected data by measuring the characteristic I$V$ curves under outdoor environmental conditions. For that reason, we also measured the consistency of the environmental conditions, meanwhile the operating voltage of photovoltaics was altered. For the obtained results, a combined standard uncertainty, calculated from the repeated measurements and the used measurement instruments, of $\pm 3 \%$ is considered.

Table VII summarises the obtained power in the MPP $\left(P_{m p p}\right)$ for the PV cells in the different rows at different solar altitude angles. Similar to the calculation of the effective area, the values for measured power were normalised. Here, $100 \%$ represents the highest value for the power in MPP $\left(P_{m p p}\right)$, which was measured in a particular row $(i)$, calculated as follows

$$
\hat{P}_{m p p}=\frac{P_{m p p, i}}{P_{m p p, \max }} \quad \text { whereas } \quad i=1,2, \ldots, 8,9
$$

Table VIII presents the normalised power in the MPP $\left(\hat{P}_{m p p}\right)$. This table is used for the comparison of the experimental results with the calculated normalised effective area $\left(\hat{A}_{e f f}\right)$. An error $\varepsilon$ between $\hat{A}_{\text {eff }}$ and $\hat{P}_{m p p}$ is calculated for every row, as calculated in Equation (5). Fig 8 shows the obtained mean value of the error $(\bar{\varepsilon})$ between $\hat{A}_{\text {eff }}$ and $\hat{P}_{m p p}$ for different rows of PV cells. As seen in Fig. 8, there is a good agreement between the calculated effective area and the obtained power the MPP. The error including the standard deviation is less than $2.5 \%$. In this way, the effective area can be used for considering different longitudinal angles of PV cells on top of curved surfaces and calculating the output power at different longitudinal angles.

$$
\varepsilon_{i}=\hat{A}_{e f f, i}-\hat{P}_{m p p, i} \quad \text { whereas } \quad i=1,2, \ldots, 8,9
$$

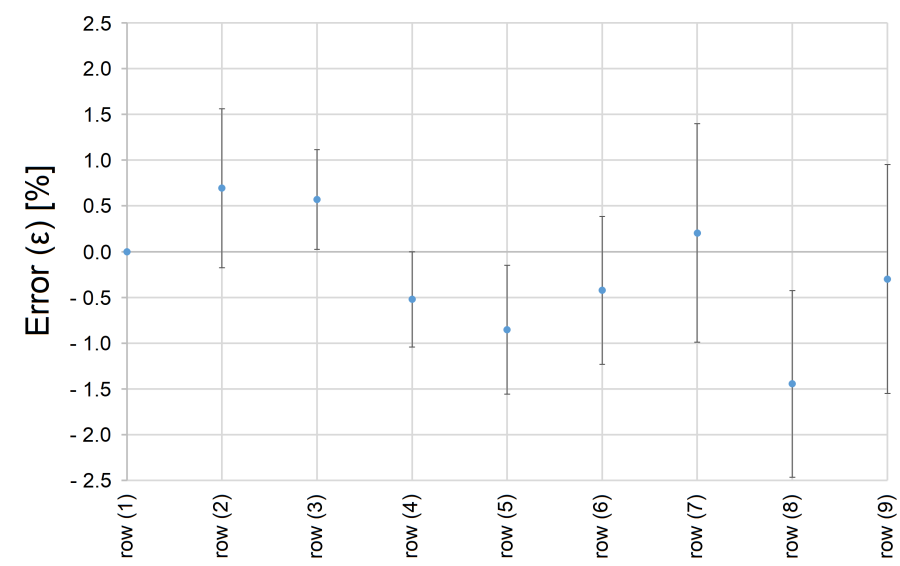

Fig. 8. $\bar{\varepsilon}$ between $\hat{A}_{\text {eff }}$ and $\hat{P}_{m p p}$ for different rows of PV cells

By calculating the effective area, there is no need to measure the ambient conditions for PV cells with different longitudinal angles. For example, the conditions can be measured for the PV cell in row (6) with $\beta=0^{\circ}$, and then the differences can be estimated for PV cells in other rows. Similarly, the power in the MPP needs to be obtained only from one PV cell in one row and can then be estimated for other rows. As BEVs and HEVs have varying roof shapes and allow different amounts 
TABLE V

Calculated effective ARea of PV Cells $\left(A_{e f f}\right)$ AT Different solar Altitude Angles $(\alpha), \alpha=38^{\circ}$ To $44^{\circ}$

\begin{tabular}{|c|c|c|c|c|c|c|c|}
\cline { 2 - 8 } \multicolumn{1}{c|}{} & $\alpha=38^{\circ}$ & $\alpha=39^{\circ}$ & $\alpha=40^{\circ}$ & $\alpha=41^{\circ}$ & $\alpha=42^{\circ}$ & $\alpha=43^{\circ}$ & $\alpha=44^{\circ}$ \\
\hline row (1) & $79.86 \%$ & $80.90 \%$ & $81.92 \%$ & $82.90 \%$ & $83.87 \%$ & $84.80 \%$ & $85.72 \%$ \\
\hline row (2) & $75.47 \%$ & $76.60 \%$ & $77.71 \%$ & $78.80 \%$ & $79.86 \%$ & $80.90 \%$ & $81.92 \%$ \\
\hline row (3) & $73.14 \%$ & $74.31 \%$ & $75.47 \%$ & $76.60 \%$ & $77.71 \%$ & $78.80 \%$ & $79.86 \%$ \\
\hline row (4) & $65.61 \%$ & $66.91 \%$ & $68.20 \%$ & $69.47 \%$ & $70.71 \%$ & $71.93 \%$ & $73.14 \%$ \\
\hline row (5) & $64.28 \%$ & $65.61 \%$ & $66.91 \%$ & $68.20 \%$ & $69.47 \%$ & $70.71 \%$ & $71.93 \%$ \\
\hline row (6) & $61.57 \%$ & $62.93 \%$ & $64.28 \%$ & $65.61 \%$ & $66.91 \%$ & $68.20 \%$ & $69.47 \%$ \\
\hline row (7) & $55.92 \%$ & $57.36 \%$ & $58.78 \%$ & $60.18 \%$ & $61.57 \%$ & $62.93 \%$ & $64.28 \%$ \\
\hline row (8) & $50.00 \%$ & $51.50 \%$ & $52.99 \%$ & $54.46 \%$ & $55.92 \%$ & $57.36 \%$ & $58.78 \%$ \\
\hline row (9) & $46.95 \%$ & $48.48 \%$ & $50.00 \%$ & $51.50 \%$ & $52.99 \%$ & $54.46 \%$ & $55.92 \%$ \\
\hline
\end{tabular}

TABLE VI

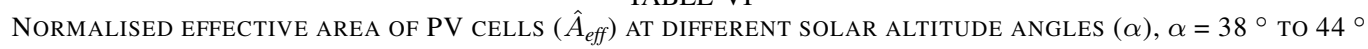

\begin{tabular}{|c|c|c|c|c|c|c|c|}
\cline { 2 - 8 } \multicolumn{1}{c|}{} & $\alpha=38^{\circ}$ & $\alpha=39^{\circ}$ & $\alpha=40^{\circ}$ & $\alpha=41^{\circ}$ & $\alpha=42^{\circ}$ & $\alpha=43^{\circ}$ & $\alpha=44{ }^{\circ}$ \\
\hline row (1) & $100.00 \%$ & $100.00 \%$ & $100.00 \%$ & $100.00 \%$ & $100.00 \%$ & $100.00 \%$ & $100.00 \%$ \\
\hline row (2) & $94.50 \%$ & $94.69 \%$ & $94.87 \%$ & $95.05 \%$ & $95.23 \%$ & $95.40 \%$ & $95.57 \%$ \\
\hline row (3) & $91.58 \%$ & $91.86 \%$ & $92.13 \%$ & $92.40 \%$ & $92.66 \%$ & $92.92 \%$ & $93.17 \%$ \\
\hline row (4) & $82.15 \%$ & $82.71 \%$ & $83.26 \%$ & $83.79 \%$ & $84.31 \%$ & $84.82 \%$ & $85.32 \%$ \\
\hline row (5) & $80.49 \%$ & $81.09 \%$ & $81.69 \%$ & $82.26 \%$ & $82.83 \%$ & $83.38 \%$ & $83.92 \%$ \\
\hline row (6) & $77.09 \%$ & $77.79 \%$ & $78.47 \%$ & $79.14 \%$ & $79.78 \%$ & $80.42 \%$ & $81.04 \%$ \\
\hline row (7) & $70.02 \%$ & $70.90 \%$ & $71.76 \%$ & $72.59 \%$ & $73.41 \%$ & $74.21 \%$ & $74.99 \%$ \\
\hline row (8) & $62.61 \%$ & $63.66 \%$ & $64.69 \%$ & $65.70 \%$ & $66.68 \%$ & $67.63 \%$ & $68.57 \%$ \\
\hline row (9) & $58.78 \%$ & $59.93 \%$ & $61.04 \%$ & $62.12 \%$ & $63.19 \%$ & $64.22 \%$ & $65.24 \%$ \\
\hline
\end{tabular}

TABLE VII

ObTAINED POWER IN THE MPP $\left(P_{m p p}\right)$ AT DifFERENT SOLAR ALtitude ANGLES $(\alpha), \alpha=38^{\circ}$ TO $44^{\circ}$

\begin{tabular}{|c|c|c|c|c|c|c|c|}
\cline { 2 - 8 } \multicolumn{1}{c|}{} & $\alpha=38^{\circ}$ & $\alpha=39^{\circ}$ & $\alpha=40^{\circ}$ & $\alpha=41^{\circ}$ & $\alpha=42^{\circ}$ & $\alpha=43^{\circ}$ & $\alpha=44^{\circ}$ \\
\hline row (1) & $3.12 \mathrm{~W}$ & $3.21 \mathrm{~W}$ & $3.42 \mathrm{~W}$ & $3.39 \mathrm{~W}$ & $3.36 \mathrm{~W}$ & $3.42 \mathrm{~W}$ & $3.47 \mathrm{~W}$ \\
\hline row $(2)$ & $2.90 \mathrm{~W}$ & $3.03 \mathrm{~W}$ & $3.19 \mathrm{~W}$ & $3.18 \mathrm{~W}$ & $3.21 \mathrm{~W}$ & $3.28 \mathrm{~W}$ & $3.31 \mathrm{~W}$ \\
\hline row $(3)$ & $2.84 \mathrm{~W}$ & $2.91 \mathrm{~W}$ & $3.12 \mathrm{~W}$ & $3.12 \mathrm{~W}$ & $3.09 \mathrm{~W}$ & $3.17 \mathrm{~W}$ & $3.25 \mathrm{~W}$ \\
\hline row $(4)$ & $2.61 \mathrm{~W}$ & $2.65 \mathrm{~W}$ & $2.85 \mathrm{~W}$ & $2.85 \mathrm{~W}$ & $2.86 \mathrm{~W}$ & $2.92 \mathrm{~W}$ & $2.98 \mathrm{~W}$ \\
\hline row $(5)$ & $2.52 \mathrm{~W}$ & $2.64 \mathrm{~W}$ & $2.79 \mathrm{~W}$ & $2.81 \mathrm{~W}$ & $2.85 \mathrm{~W}$ & $2.88 \mathrm{~W}$ & $2.96 \mathrm{~W}$ \\
\hline row $(6)$ & $2.42 \mathrm{~W}$ & $2.51 \mathrm{~W}$ & $2.65 \mathrm{~W}$ & $2.69 \mathrm{~W}$ & $2.74 \mathrm{~W}$ & $2.78 \mathrm{~W}$ & $2.83 \mathrm{~W}$ \\
\hline row $(7)$ & $2.14 \mathrm{~W}$ & $2.25 \mathrm{~W}$ & $2.42 \mathrm{~W}$ & $2.43 \mathrm{~W}$ & $2.48 \mathrm{~W}$ & $2.60 \mathrm{~W}$ & $2.63 \mathrm{~W}$ \\
\hline row $(8)$ & $1.96 \mathrm{~W}$ & $2.08 \mathrm{~W}$ & $2.28 \mathrm{~W}$ & $2.29 \mathrm{~W}$ & $2.35 \mathrm{~W}$ & $2.35 \mathrm{~W}$ & $2.41 \mathrm{~W}$ \\
\hline row $(9)$ & $1.86 \mathrm{~W}$ & $1.94 \mathrm{~W}$ & $2.03 \mathrm{~W}$ & $2.10 \mathrm{~W}$ & $2.18 \mathrm{~W}$ & $2.18 \mathrm{~W}$ & $2.29 \mathrm{~W}$ \\
\hline
\end{tabular}

TABLE VIII

NORMALISED POWER IN THE MPP $\left(\hat{P}_{m p p}\right)$ AT DIFFERENT SOLAR ALtitude ANGLES $(\alpha), \alpha=38^{\circ}$ TO $44^{\circ}$

\begin{tabular}{|c|c|c|c|c|c|c|c|}
\cline { 2 - 8 } \multicolumn{1}{c|}{} & $\alpha=38^{\circ}$ & $\alpha=39^{\circ}$ & $\alpha=40^{\circ}$ & $\alpha=41^{\circ}$ & $\alpha=42^{\circ}$ & $\alpha=43^{\circ}$ & $\alpha=44{ }^{\circ}$ \\
\hline row (1) & $100.00 \%$ & $100.00 \%$ & $100.00 \%$ & $100.00 \%$ & $100.00 \%$ & $100.00 \%$ & $100.00 \%$ \\
\hline row (2) & $92.88 \%$ & $94.33 \%$ & $93.10 \%$ & $93.71 \%$ & $95.39 \%$ & $95.73 \%$ & $95.32 \%$ \\
\hline row (3) & $90.93 \%$ & $90.54 \%$ & $91.33 \%$ & $91.89 \%$ & $91.91 \%$ & $92.49 \%$ & $93.65 \%$ \\
\hline row (4) & $83.63 \%$ & $82.62 \%$ & $83.36 \%$ & $84.09 \%$ & $85.15 \%$ & $85.37 \%$ & $85.79 \%$ \\
\hline row (5) & $80.78 \%$ & $82.27 \%$ & $81.59 \%$ & $82.87 \%$ & $84.81 \%$ & $84.03 \%$ & $85.28 \%$ \\
\hline row (6) & $77.58 \%$ & $78.19 \%$ & $77.40 \%$ & $79.37 \%$ & $81.40 \%$ & $81.30 \%$ & $81.45 \%$ \\
\hline row (7) & $68.51 \%$ & $70.04 \%$ & $70.80 \%$ & $71.68 \%$ & $73.72 \%$ & $76.11 \%$ & $75.59 \%$ \\
\hline row (8) & $62.81 \%$ & $64.72 \%$ & $66.73 \%$ & $67.48 \%$ & $69.97 \%$ & $68.53 \%$ & $69.41 \%$ \\
\hline row (9) & $59.61 \%$ & $60.46 \%$ & $59.29 \%$ & $61.89 \%$ & $64.85 \%$ & $63.60 \%$ & $66.06 \%$ \\
\hline
\end{tabular}

of PV cells with different longitudinal angles, the effective area is helpful to investigate the mismatch in terms of output power between PV cells. Here, the effective area can be used as an indicator to determine suitable interconnections of PV 
cells to form a PV panel, in particular for different types of vehicles than the experimental vehicle shown in Fig. 4

\section{B. PV Installations in Stationary Conditions}

In our analyses, we concentrate on the experimental conditions from Tables V.VIII, in other words $\alpha=38^{\circ}$ to $44^{\circ}$. Connecting the PV cells of the installation as seen in Fig. 5 in parallel, in other words attempting to obtain the individual power of each PV cell, the power in the MPP $\left(P_{m p p}\right)$ of each PV cell can be summed up to obtain the total power in the MPP $\left(P_{m p p, t o t a l}\right)$ of the PV installation as follows

$$
P_{m p p, t o t a l}=\sum_{i=1}^{9} 5 \times P_{m p p, i}
$$

If the longitudinal angle $(\beta)$ of all PV cells would be the same, then $N_{p}=45$. However, since only PV cells in the same row have the same longitudinal angle, $N_{p}=5$. When connecting all PV cells of the installation in series, $N_{s}=45$ and $N_{p}=1$. However, as stated in Equation (6), the short-circuit current $\left(I_{s c}\right)$ of the interconnection depends on the weakest PV cell of the interconnection, in other words, a PV cell located in row (9) for the given solar altitude angles $\left(\alpha=38^{\circ}\right.$ to $\left.44^{\circ}\right)$. As a result, the total power in the MPP $\left(P_{m p p, t o t a l}\right)$ is obtained as follows

$$
P_{m p p, t o t a l}=45 \times P_{m p p, 9}
$$

Table IX summarises the obtained results of the total power in the MPP $\left(P_{\text {mpp,total }}\right)$ for the two different types of interconnections, including the difference between them. As seen in Table IX] on average, about $25 \%$ less power can be obtained from a series connection than from a parallel connection of PV cells. However, even though a parallel connection offers a higher power in the MPP, in practice, it is diffucult to establish this type of connection. As a comprise, PV cells on the roof of BEVs and HEVs could be connected with each other to form small PV panels.

TABLE IX

$P_{m p p, t o t a l}$ FOR SERIES AND PARALLEL INTERCONNECTIONS

\begin{tabular}{|c|c|c|c|}
\cline { 2 - 4 } \multicolumn{1}{c|}{} & in parallel & in series & difference \\
\hline$\alpha=38^{\circ}$ & $111.85 \mathrm{~W}$ & $83.70 \mathrm{~W}$ & $-25.17 \%$ \\
\hline$\alpha=39^{\circ}$ & $116.10 \mathrm{~W}$ & $87.30 \mathrm{~W}$ & $-24.81 \%$ \\
\hline$\alpha=40^{\circ}$ & $123.75 \mathrm{~W}$ & $91.35 \mathrm{~W}$ & $-26.18 \%$ \\
\hline$\alpha=41^{\circ}$ & $124.30 \mathrm{~W}$ & $94.50 \mathrm{~W}$ & $-23.97 \%$ \\
\hline$\alpha=42^{\circ}$ & $125.60 \mathrm{~W}$ & $98.10 \mathrm{~W}$ & $-21.89 \%$ \\
\hline$\alpha=43^{\circ}$ & $127.90 \mathrm{~W}$ & $98.10 \mathrm{~W}$ & $-23.30 \%$ \\
\hline$\alpha=44^{\circ}$ & $130.75 \mathrm{~W}$ & $103.05 \mathrm{~W}$ & $-21.19 \%$ \\
\hline
\end{tabular}

\section{PV Installations in Moving Conditions}

Fig. 9 illustrates the map of the street for the measurements. Measurements were collected by driving from the school in the North to the chapel in the South. At first, the vehicle passed through a tree avenue in which trees are located at both sides of the road. Afterwards, the vehicle passed through an area in

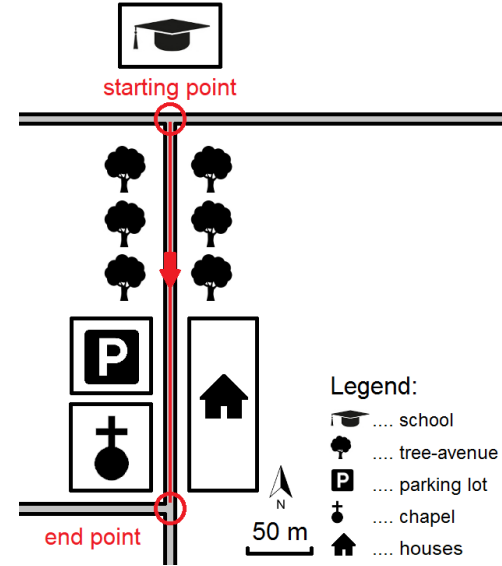

Fig. 9. Map of the street for the measurements

which a parking lot and a chapel were located on the righthand side of the street (driver's perspective), while houses were located on the left-hand side of the street. The driving distance was about $220 \mathrm{~m}$ and the vehicle's speed was about $40 \mathrm{~km} / \mathrm{h}$.

In the experiments, 8 measurement probes were used to sense the solar radiation level $(\lambda)$. The probes and their calibration are described in [24]. Three measurement probes $(1,4$, and 6$)$ are located on the left-hand side of the vehicle's roof, two measurement probes (2 and 7) are located in the middle of the vehicle's roof, and three measurement probes $(3,5$, and 8$)$ are located on the right-hand side of the vehicle's roof. The location of the measurement probes is in relation to the PV cells of the installation, which is shown in Fig. 5

Figs. 10 12 show the measurement results based on the location of the probe on the vehicle's roof. When comparing the available solar radiation level $(\lambda)$ in Figs. 10 12, we can see a significant difference between the left-hand side and the right-hand side of the vehicle's roof. For example, the duration of full sunlight $\left(\lambda \approx 800 \mathrm{~W} / \mathrm{m}^{2}\right)$ is much shorter on the right-hand side of the vehicle's roof in comparison to the left-hand side of the vehicle's roof. For the different measurement probes, the following average solar radiation level $(\bar{\lambda})$ is obtained:

$\begin{array}{ll}\text { probe } 1 \text { [row (1), line (1)]: } & \bar{\lambda}=565 \pm 310 \mathrm{~W} / \mathrm{m}^{2} \\ \text { probe } 2 \text { [row (1), line (3)]: } & \bar{\lambda}=478 \pm 325 \mathrm{~W} / \mathrm{m}^{2} \\ \text { probe } 3 \text { [row (1), line (5)]: } & \bar{\lambda}=399 \pm 320 \mathrm{~W} / \mathrm{m}^{2} \\ \text { probe } 4 \text { [row (5), line (1)]: } & \bar{\lambda}=572 \pm 310 \mathrm{~W} / \mathrm{m}^{2} \\ \text { probe } 5 \text { [row (5), line (5)]: } & \bar{\lambda}=398 \pm 319 \mathrm{~W} / \mathrm{m}^{2} \\ \text { probe } 6 \text { [row (9), line (1)]: } & \bar{\lambda}=581 \pm 305 \mathrm{~W} / \mathrm{m}^{2} \\ \text { probe } 7 \text { [row (9), line (3)]: } & \bar{\lambda}=477 \pm 316 \mathrm{~W} / \mathrm{m}^{2} \\ \text { probe } 8 \text { [row (9), line (5)]: } & \bar{\lambda}=398 \pm 316 \mathrm{~W} / \mathrm{m}^{2}\end{array}$

Based on the obtained measurement results, it can be stated that frequent shading of PV cells, which occur when driving through urban areas, cause an uneven amount of solar radiation level $(\lambda)$ on the PV installation on top of vehicles. On average, $\lambda$ is about $30 \%$ lower on the right-hand side of the vehicle's roof than on the left-hand side. With the dependence of the short-circuit current $\left(I_{s c}\right)$ on the weakest PV cell of the interconnection, these circumstances have an impact on 


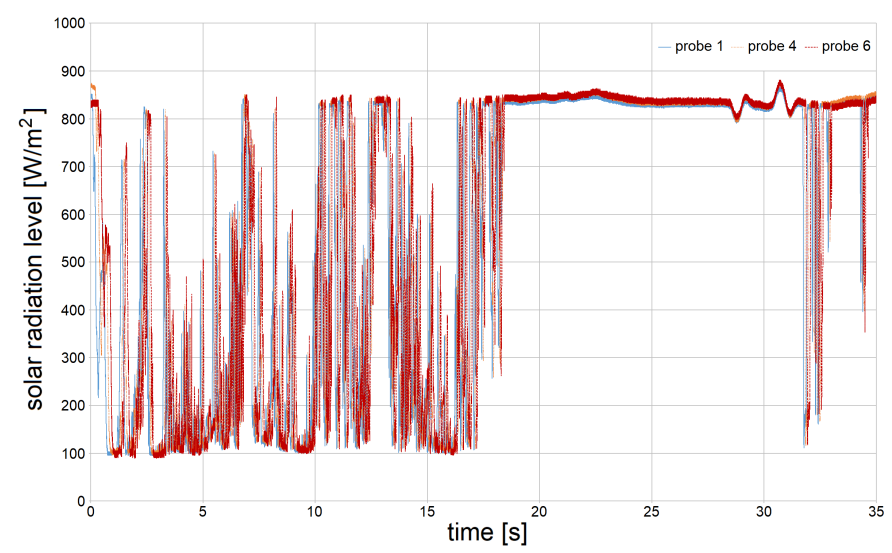

Fig. 10. Solar radiation level $(\lambda)$ on the left-hand side of the vehicle's roof

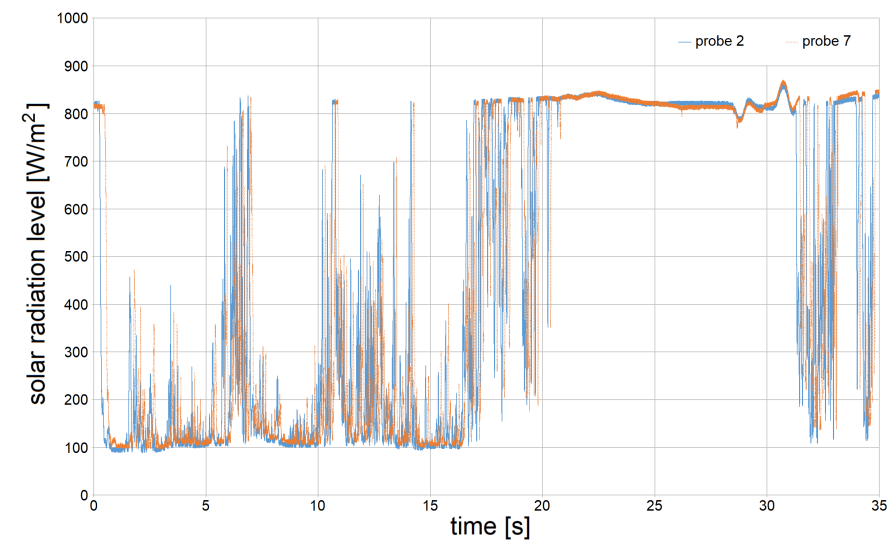

Fig. 11. Solar radiation level $(\lambda)$ in the middle of the vehicle's roof

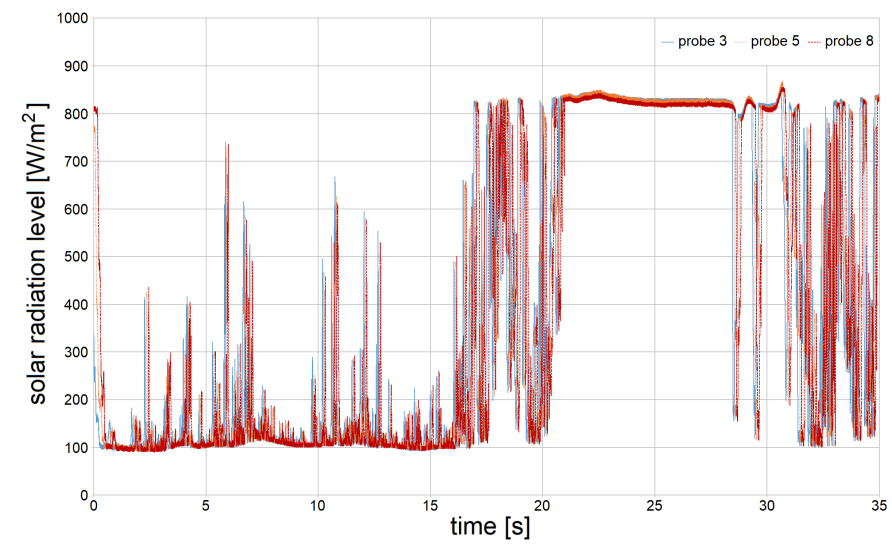

Fig. 12. Solar radiation level $(\lambda)$ on the right-hand side of the vehicle's roof

possible interconnections of $\mathrm{PV}$ cells, in particular a series connection between vertical PV cells, i.e. line (1) to (5).

As discussed above, in the case of stationary conditions, the curved surface of the vehicle's roof causes a different alignment of each PV cell towards the sun. As a result, each PV cell in a different row receives a different solar radiation level. However, in moving conditions, the solar radiation level can change frequently and, thus, is different for PV cells in the same row. Fig. 13 shows the minimum and maximum solar radiation level $\left(\lambda_{\min }\right.$ and $\left.\lambda_{\max }\right)$ of the 8 measurement probes at

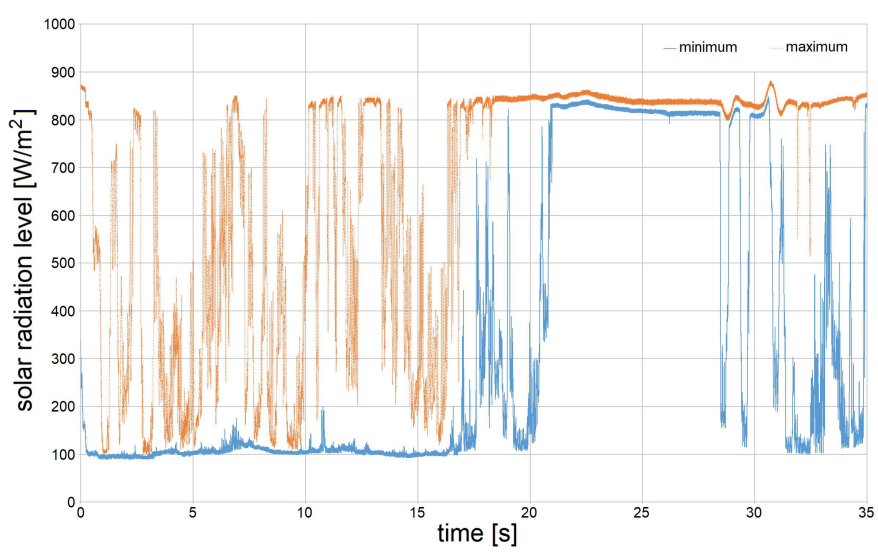

Fig. 13. Minimum and maximum solar radiation level $\left(\lambda_{\min }\right.$ and $\left.\lambda_{\max }\right)$

a given time. As seen in Fig. 13, even though the area of the vehicle's roof is only about $1.5 \mathrm{~m}^{2}$, there is a large variation in the available solar radiation level variation.

If a series connection of PV cells is established, it is likely that moving conditions will cause shading of one of the PV cells of the interconnection at a given time. As a result, the entire interconnection provides $I_{s c, \text { min }}$ given by the $\lambda_{\text {min }}$, even though other PV cells of the interconnetion receive a much higher solar radiation level (up to $\lambda_{\max }$ ). For the given measurement scenario shown in Fig. 9. a series interconnection produces on average about $50 \%$ less power in comparison to a parallel interconnection. However, when driving for example through tree avenues (i.e. during which $\lambda_{\min } \approx 100 \mathrm{~W} / \mathrm{m}^{2}$ ), on average, about $75 \%$ less power is obtained.

\section{Discussion}

It is worth noting that PV installations on top of BEVs and HEVs represent a new environment for PV energy systems. In this paper, we analysed various aspects for PV installations in these new types of environments. Firstly, the available area on top of vehicles is limited and on average 1.5 to $2 \mathrm{~m}^{2}$ can be used for the deployment of PV cells. On the experimental vehicle, a Toyota Prius, 9 rows with 5 PV cells in each row (i.e. $45 \mathrm{PV}$ cells in total) were installed. Secondly, due to the curved surface of the roof of a BEV or HEV, each PV cell within a row is aligned towards the sun under a different longitudinal angle.

As a result, conventional approaches for PV simulation models cannot be used for calculating the potential output power of PV installations on top of BEVs and HEVs. In contrast to flat surfaces, in which each PV cell of a panel receives without shading the same solar radiation level, curved surfaces do not allow to simply sum up the power provided by individual PV cells to obtain the total output power. Hence, we presented the concept of the effective area of a PV cell, which allows to take into account the different longitudinal angles of PV cells towards the sun for PV simulation models.

As parallel interconnections of PV cells are unpractical, commonly, all PV cells within a panel are connected in series with each other. However, such series connections result in significant losses in output power. We investigated the 
circumstances for both, stationary and moving PV installations. Based on our experiments and simulations, we can state that in particular during driving conditions, the available solar radiation level is different for every PV cell in the interconnection. Thus, series connections result in substantial losses, as the total output power depends on the weakest PV cell of the interconnection. Of course, it is worth noting that the exact impacts on the available output power depend on various parameters such as the geographical location, time of the day, time of the year, speed of the vehicle, to name a few.

In commercial solutions for PV installations on top of BEVs and HEVs, due to the curved shape of the roof of vehicles, it simply does not make sense to connect PV cells in series. As seen in Figs. 10 12, different areas of the roof, from the left-hand side to the right-hand side, will receive a different solar radiation level, ranging from a minimum solar radiation level $\left(\lambda_{\min }\right)$ to a maximum solar radiation level $\left(\lambda_{\max }\right)$, as seen in Fig. 13 In our experiments, the difference between $\lambda_{\min }$ and $\lambda_{\max }$ was as large as $725 \mathrm{~W} / \mathrm{m}^{2}$ or about $85 \%$.

At present, car manufacturers consider supplying various systems with the energy gained from a PV installation on the roof of an electric vehicle. In driving conditions, these systems include for example the vehicle's lights, air conditioning system, navigation, and auxiliary systems such as window openers. However, within a series connection, the available output power will fluctuate significantly and can cause potential problems in the stability of the systems power supply as well as in the vehicle's onboard power supply.

\section{CONCLUSION}

On top of flat surfaces, each PV cell of a PV panel faces the sun under the same angle. Hence, the solar radiation level is equal for every PV cell. In a PV simulation model, the output power of one PV cell is calculated and then multiplied by the factor $N_{s}$ for the typical series interconnection (and $\left.N_{p}=1\right)$. However, if PV cells are mounted onto the top of curved surfaces such as the roof of BEVs and HEVs, each PV cell in a row of the installation is oriented under a different longitudinal angle towards the sun.

We demonstrated that the effective area is a simple way to estimate the available power in the MPP of PV cells with different longitudinal angles and can be used for PV simulation models. By normalising values, we were able to compare the values of the calculated effective area and the obtained power in the MPP with each other. We presented experimental results for typical solar altitude angles in the City of Oulu, Finland. In our analysis, we found a strong correlation between the two different parameters. Errors were in the range of less than \pm $2.5 \%$.

Furthermore, we investigated possible interconnections of PV cells on top of BEVs and HEVs. Based on our experimental data and simulations, it can be stated that for stationary conditions, in other words when vehicles with PV installations within urban areas, about $25 \%$ less power can be obtained from a series connection of $\mathrm{PV}$ cells in comparison to a parallel connection of PV cells. However, for moving conditions, in other words when vehicles with PV installations are driving within urban areas, during frequent shading, up to $75 \%$ less power can be obtained from a series connection of PV cells in comparison to a parallel connection of PV cells.

In future work, we would like to use the effective area within PV simulation tools to determine efficient interconnections of PV cells on top of vehicles. Based on the results in this work, one possible solution can be multiple series-parallel connections of PV cells to form small PV panels in order to address the uneven distribution in the available solar radiation level. However, it will take extensive simulations and analyses, including the collection of more experimental data, to determine the most efficient type of interconnection. Furthermore, we would like to analyse other areas of the vehicles which have larger longitudinal angles for the possible deployment of PV cells.

\section{ACKNOWLEDGMENT}

The authors would like to thank M. Schuss for her help and support in setting up and carrying out the measurements. We appreciate Harald Gall, Klaus Eberhart, Hannes Illko and Suzy McAnsh for their help and comments on this research work.

\section{REFERENCES}

[1] D.P. van Vuuren, N. Nakicenovic, K. Riahi, A. Brew-Hammond, D. Kammen, V. Modi, and K. Smith, "An energy vision: The transformation towards sustainability - interconnected challenges and solutions", Current Opinion in Environmental Sustainability, vol. 4, issue: 1, pp. 18-34, 2012.

[2] S. Mekhilef, R. Saidur, and A. Safari, "A review on solar energy use in industries", Renewable and Sustainable Energy Reviews, vol. 15, issue: 4, pp. 1777-1790, 2011.

[3] C. Schuss, H. Gall, K. Eberhart, H. Illko, and B. Eichberger, "Alignment and Interconnection of Photovoltaics on Electric and Hybrid Electric Vehicles", Proceedings of the IEEE International Instrumentation and Measurement Technology Conference (I2MTC), pp. 524-527, 2014.

[4] K. Araki, L. Ji, G. Kelly, and M. Yamaguchi, "To Do List for Research and Development and International Standardization to Achieve the Goal of Running a Majority of Electric Vehicles on Solar Energy", Coatings, vol. 8, issue: 7, pp. 251, 2018.

[5] T. Masuda, K. Araki, K. Okumura, S. Urabe, Y. Kudo, K. Kimura, T. Nakado, A. Sato, and M. Yamaguchi, "Static concentrator photovoltaics for automotive applications", Solar Energy, vol. 146, pp. 523-531, 2017.

[6] K. Araki, C. Algora, G. Siefer, K. Nishioka, R. Leutz, S. Carter, S. Wang, S. Askins, L. Ji, and G. Kelly, "Standardization of the CPV and car-roof PV technology in 2018 - Where are we going to go?", AIP Conference Proceedings, vol. 2012, no. 1, p. 070001, 2018.

[7] G.C. Mouli, P. Bauer, and M. Zeman, "System design for a solar powered electric vehicle charging station for workplaces", Applied Energy, vol. 168, pp. 434-443, 2016.

[8] G. Leen, and D. Heffernan, "Expanding automotive systems", Computer, vol. 35, issue: 1, pp. 88-93, 2002.

[9] E. Karden, S. Ploumen, B. Fricke, T. Miller, and K. Snyder, "Energy storage devices for future hybrid electric vehicles", Journal of Power Sources, vol. 168, issue: 1, pp. 2-11, 2007.

[10] M.A. Hussin, A.N. Abdalla, R. Ishak, R. Abdullah, and Z.M. Ali, "Study on Improving Electric Vehicle drive range using Solar Energy", International Conference on Electrical, Control and Computer Engineering (InECCE), pp. 373-376, June 2011.

[11] C. Schuss, B. Eichberger, and T. Rahkonen, "A Monitoring System for the Use of Solar Energy in Electric and Hybrid Electric Vehicles", Proceedings of the IEEE International Instrumentation and Measurement Technology Conference (I2MTC), pp. 524-527, 2012.

[12] Y. Ota, T. Masuda, K. Araki, and M. Yamaguchi, "A mobile multipyranometer array for the assessment of solar irradiance incident on a photovoltaic-powered vehicle", Solar Energy, vol. 184, pp. 84-90, 2019.

[13] M. Yamaguchi, K.-H. Lee, K. Araki, N. Kojima, H. Yamada, and Y. Katsumata, "Analysis for efficiency potential of highefficiency and nextgeneration solar cells", Progress in Photovoltaics: Research and Applications, vol. 26, no. 8, pp. 543-552, 2018. 
[14] C. Schuss, B. Eichberger, and T. Rahkonen, "Calculating the Output Power of Photovoltaic Cells on Top of Electric and Hybrid Electric Vehicles", Proceedings of the IEEE International Instrumentation and Measurement Technology Conference (I2MTC), pp. 820-825, 2019.

[15] T. Esram, and P.L. Chapman, "Comparison of Photovoltaic Array Maximum Power Point Tracking Techniques", IEEE Transactions on Energy Conversion, vol. 22, issue: 2, pp. 439-449, 2007.

[16] R. Ramaprabha, B. Mathur, M. Murthy, and S. Madhumitha, "New Configuration of Solar Photo Voltaic Array to address Partial Shaded Conditions", $3^{\text {rd }}$ International Conference on Emerging Trends in Engineering and Technology (ICETET), article number: 5698344, pp. 328-333, 2010.

[17] L. Cai, N. Dai, Z. and Tan, "Research on mathematical model and calculation simulation of wireless sensor solar cells in Internet of Things", EURASIP Journal on Wireless Communications and Networking, vol. 1, p. 116,2018

[18] C. Schuss, and T. Rahkonen, "Adaptive Photovoltaic Cell Simulation with Maximum Power Point Tracking Simulation for Accurate Energy Predictions", NORCHIP 2011, article number 6126721, pp. 1-4, 2011.

[19] H.-L. Tsai, "Insolation-oriented model of photovoltaic module using Matlab/Simulink", Solar Energy, vol. 84, issue 7, pp. 1318-1326, 2010.

[20] C. Schuss, B. Eichberger, and T. Rahkonen, "Measurement and Verification of Photovoltaic (PV) Simulation Models", Proceedings of the IEEE International Instrumentation and Measurement Technology Conference (I2MTC), pp. 188-193, 2013.

[21] C. Schuss, K. Leppänen, Juha Saarela, Tapio Fabritius, B. Eichberger, and T. Rahkonen, "Detecting Defects in Photovoltaic Modules with the Help of Experimental Verification and Synchronized Thermography", Proceedings of the IEEE International Instrumentation and Measurement Technology Conference (I2MTC), pp. 97-102, 2015.

[22] C. Schuss, K. Remes, K. Leppänen, Juha Saarela, Tapio Fabritius, B. Eichberger, and T. Rahkonen, "Detecting Defects in Photovoltaic Cells and Panels and Evaluating the Impact on Output Performances", IEEE Transactions on Instrumentation and Measurement, vol. 65, issue: 5, pp. 1-12, 2016.

[23] C. Schuss, K. Remes, K. Leppänen, Juha Saarela, Tapio Fabritius, B. Eichberger, and T. Rahkonen, "Estimating the Impact of Defects in Photovoltaic Cells and Panels", Proceedings of the IEEE International Instrumentation and Measurement Technology Conference (I2MTC), pp. 121-126, 2016.

[24] C. Schuss, T. Fabritius, B. Eichberger, and T. Rahkonen, "Moving Photovoltaic Installations: Impacts of the Sampling Rate on Maximum Power Point Tracking Algorithms", IEEE Transactions on Instrumentation and Measurement, vol. 68, issue: 5, pp. 1485-1493, 2019.

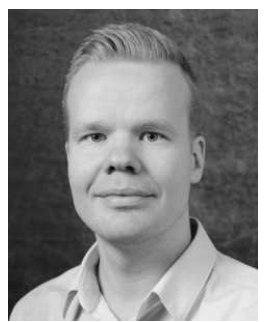

Tapio Fabritius received the M.S. and D.Sc. (Tech.) degrees in electrical engineering from the University of Oulu, Oulu, Finland, in 2003 and 2007, respectively. He was a Visiting Researcher with the Computational Optics Group, University of Tsukuba, Tsukuba, Japan, from 2006 to 2007. In 2009, he was conducting research with the Flexible Display Center, Tempe, AZ, USA. Since 2012, he has been the Research Director of PrintoCent, Oulu. He is currently the Head of the Printed Intelligence Group with the OPEM Research Unit, University of Oulu. He has co-authored over 60 papers. His current research interests include manufacturing and characterization of printed intelligence.

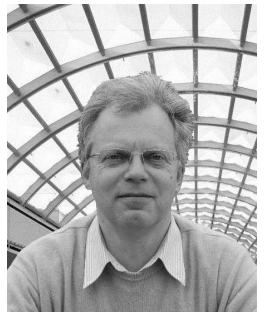

Bernd Eichberger was born in Bruck an der Mur, Austria, in 1961. He received the Diploma and Dr.Techn. (Hons.) degrees in electrical engineering from the Graz University of Technology, Graz, Austria, in 1990 and 1994, respectively.

$\mathrm{He}$ is currently a Professor with the Institute of Electronic Sensor Systems, Graz University of Technology. His current research interests include industrial and automotive electronic circuits and systems, new test and measurement principles, electronic engine control units, and fuel cell and lithiumion battery monitoring and diagnosis.

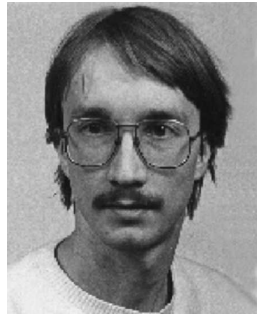

Timo Rahkonen (S'88-M'90) was born in Jyväskylä, Finland, in 1962. He received the Diploma Engineering, Licentiate, and D.Tech. degrees from the University of Oulu, Oulu, Finland, in 1986, 1991, and 1994, respectively.

$\mathrm{He}$ is currently a Professor of Circuit Theory and Circuit Design with the CAS Resaerch Unit and Infotech Oulu, University of Oulu, where he conducts research on linearization and error correction techniques for RF power amplifiers and $\mathrm{A} / \mathrm{D}$ and $\mathrm{D} / \mathrm{A}$ converters.

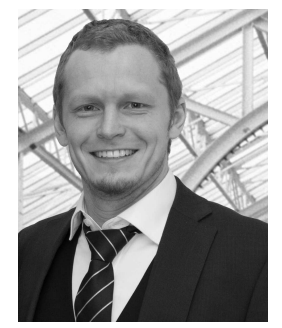

Christian Schuss (S'11-M'17) was born in Lienz, Austria, in 1983. He received the Dipl.-Ing. (Hons.) degree in information technology and the Dr.Techn. degree in automotive electronics from the Graz University of Technology, Graz, Austria, in 2010 and 2014, respectively, and the D.Sc. (Tech.) degree in electronics design from the University of Oulu, Oulu, Finland in 2017. He is currently a Research and Teaching Assistant with the Circuits and Systems (CAS) Research Unit, University of Oulu, Oulu, Finland.

His current research interests include renewable energy resources, energy harvesting and automotive electronics. 